\title{
The Comparisons of Curriculum 2013, KMA 1652014 and KMA 183 2019: Do They Support Students' Literacy?
}

\author{
Nurul Aini, ${ }^{1, *}$ \\ ${ }^{1}$ Teacher of MAN 1 Cilacap, MAN 1 Cilacap, Cilacap, Indonesia \\ *Corresponding author. Email: aininrstu24@gmail.com
}

\begin{abstract}
This study aims to determine the similarities and differences of Arabic material in Islamic Senior High School between Decree of Ministry of Religious Affairs (KMA) number 165 of 2014 and KMA number 183 of 2019 and to determine the advantages and disadvantages both of them. This research is literature research. The data sources for this research are the Decree of Ministry of Religious Affairs (KMA) number 183 of 2019 concerning Islamic Education and Arabic Language Curriculum at Islamic Senior High School and the Decree of Ministry of Religious Affairs (KMA) number 165 of 2014 concerning the Curriculum 2013 for Islamic Education Subjects and Arabic Language at Islamic Senior High School. Analytical technique of this research is analytical content. The result of this study showed that the similarities of the Decree of Ministry of Religious Affairs number 165 of 2014 and number183 of 2019 are about the themes that related to introductions, family, hobbies, public facilities, health, tourism, Islamic civilization, and Islamic figures. In terms of the criteria for selecting the material, both of them are appropriate. Meanwhile, the difference is that in Decree of Ministry of Religious Affairs Number 183 of 2019, there are material that has not been discussed at Decree of Ministry of Religious Affairs Number 165 of 2014, including other topics related to media and technology, food and beverage, markets, religion in Indonesia and universities. In terms of grammatical material, the difference between Decree of Ministry of Religious Affairs Number 183 of 2019, the discussion is more structured from the basic level at a higher level such as from word, pronoun, and sentences. Whereas at Decree of Ministry of Religious Affairs Number 165 of 2014 the grammatical material arrangement was more random but more specific.
\end{abstract}

Keywords: Material, Decree of religious affairs ministry, Curriculum, Literacy.

\section{INTRODUCTION}

Curriculum is the most important part of education. Educational institutions without curriculum is nothing. It can be said that the curriculum is the core of education and it must be made carefully. According to Regulation Number 20 of 2003 concerning the National Education System, the curriculum is a set of plans and arrangements regarding the objectives, content, and learning materials as well as the methods used as guidelines for the implementation of learning activities to achieve certain educational goals. Based on this understanding, there are two dimensions of the curriculum, the first is plans and arrangements regarding objectives, content, and learning materials. While the second is the method used to administer learning process [1].
The curriculum is dynamic, meaning that curriculum development must be in accordance with the times. Curriculum development needs to be done because of the various challenges faced, both internal challenges and external challenges. Besides that, in facing the demands of the times, it is necessary to improve the mindset and strengthen curriculum governance as well as deepen and expand the material. In addition, what is no less important is the need to strengthen the learning process and adjust the learning load in order to ensure conformity between what is desired and what is produced [2].

The Decree of Ministry of Religious Affairs (or henceforth referred to as KMA) Number 183 of 2019 concerning Islamic Education Curriculum and Arabic Language in Islamic Senior High School is a decree made by the Ministry of Religious Affairs of the Republic of Indonesia as an effort to respond to the very fast changing 
times and demands of the global world. KMA Number 183 of 2019 is a change from KMA Number 165 of 2014. This curriculum change was made because Islamic Senior High School as an influential educational unit in Indonesian society must be able to respond and anticipate these changes and the demands of the global world to not be left behind. The Islamic Education and Arabic Language curriculum is directed at preparing Islamic Senior High School students to adapt on various changes in the future, with that they can produce graduates who are compatible with the demands of the times in building an advanced nation's civilization.

Based on the Decree of Ministry of Religious Affairs Number 183 of 2019, the scope of the Islamic Education and Arabic Language curriculum in Islamic Senior High School includes: 1) basic curriculum framework, 2) graduate competency standards and content standards, 3) learning, 4) assessment, 5) core competencies (KI) and basic competencies (KD). From the five scopes, content standards are an important part of the curriculum. Content standards are criteria regarding the scope of the material and the level of competence to achieve competence in an education within a certain level and type of education.

One of the changes in KMA Number 183 of 2019 that occurred was in the scope of content standards in which it was related to subject matter. Subject matter is a means used to achieve teaching and learning objectives. The subject matter can be in the form of various materials, such as a script, problems, pictures, audio cassette content, video cassette content, preparations, discussion topics with students, answers from students and more. Teaching materials contain relevant facts, concepts, principles, and procedures and are written in the form of points in accordance with the formulation of indicators of competency achievement that must be achieved by students [3]. In that sense, the subject matter is the material used for learning in order to achieve the learning objectives. Therefore, with the direction of learning objectives that change according to changing times and global demands, the subject matter must also change according to these changes.

One of the changes from KMA Number 165 of 2014 to KMA number 183 of 2019 for Example in KMA number 183 of 2019 discussed topics about media and technology, modern market, and so on, but in KMA Number 165 of 2014 has been not discussed. Besides that, in terms of grammatical material, the discussion is more structured from the basic level at a higher level such as from word, pronoun, and sentences.

From the description of these changes, there is an urge to examine more deeply about the changes that occurred from KMA Number 165 of 2014 to KMA Number 183 of 2019 and conduct a comparative study of the two. This study is expected to be able to find differences and similarities between the two Decrees by
Ministry of Religious Affairs, and it is hoped that they could find existing weaknesses and strengths and could be used as guidelines for further curriculum development. For further advantage, it can help Arabic language teachers to understand the essence of the changes that occurred at KMA Number 183 of 2019 particularly in the scope of Arabic subject matter at the Islamic Senior High School level.

From the background of the problems that have been described, the formulation of the problem can be as follows: 1) the similarities and differences in the material in KMA Number 165 of 2014 and KMA Number 183 of 2019 2) the advantages and disadvantages of material in KMA Number 165 of 2014 and KMA Number 183 of 2019.

\section{METHODS}

The method used in this research is library research. It is done to examine and analyze library data sources. The data sources for this research are the Decree of Ministry of Religious Affairs Number 183 of 2019 concerning Islamic Education and Arabic Curriculum in Islamic Senior High School and the Decree of Ministry of Religious Affairs of the Republic of Indonesia Number 165 of 2014 concerning the 2013 Curriculum for Islamic Education Subjects and Arabic Language at Islamic Senior High School. The data collection techniques in library research according to Kuhlthau are as follows: topic selection, information exploration, determining research focus, collecting data sources, preparing data presentation and preparing reports [4]. The data analysis technique used in this research is content analysis, which is a research in-depth discussion of the content of written or printed information in the mass media [5].

\section{RESULTS AND DISCUSSION}

\subsection{Theory}

Learning Materials are knowledge, skills, and attitudes that must be mastered by students in order to meet predetermined competency standards. The material specified in the learning activities should be material that really supports the achievement of competency standards and basic competencies, as well as the achievement of indicators [6].

According to Wina, subject materials are self-directed learning packages containing one topic or unit of study and require study time several times for one week. The main purpose of teaching materials is to increase the efficiency and effectiveness of learning in schools, both time, funds, facilities and energy in order to achieve the goals optimally [7].

The types of learning materials according to Isdisusilo include: 
1. Facts are all things that are in the form of reality and truth, including names of objects, historical events, symbols, place names, names of people, names of parts or components of an object and more.

2. Concepts, it is everything in the form of new understandings that can arise as a result of thinking, including definitions, understanding, special characteristics, essence, core/content and more.

3. Principles, it is in the form of the main point, principal, and have the most important positions, including theorems, formulas, adages, postulates, paradigms, theorems, and relationships between concepts that describe causal implications.

4. Procedure, which is a systematic or sequential steps in working on an activity and the chronology of a system.

5. Attitude or value is the result of learning aspects of attitude, for example the value of honesty, compassion, helping, enthusiasm and interest in learning and working and more.

According to W. S. Winkel, the criteria for selecting the right subject matter are as follows:

a. Subject materials must be relevant to the teaching and learning objectives that must be achieved.

b. The subject matter must be in accordance with the level of difficulty with the student's ability to receive and process the material.

c. The subject materials must be able to support students' motivation, among others, because they are relevant to students' daily life experiences, as far as it is possible.

d. Learning materials must be in accordance with the following dictate procedures.

e. Learning materials must be in accordance with the available teaching media [8].

Therefore, the process of delivering subject materials must follow the right order. This is because the subject matter has a hierarchy among its components. In addition, subject matter needs to be structured according to a hierarchy of intermediate objectives. In essence, subject matter needs to be structured starting from lowerlevel intellectual skills to higher-level skills.

According the Decree of Ministry of Religious Affairs Number 183 of 2019 concerning Islamic Education and Arabic Curriculum in Islamic Senior High School, characteristics of suitability, adequacy, breadth, and depth of the material are determined according to the characteristics of the competencies and the process of acquiring these competencies. The three competencies have different acquisition processes. Attitudes are formed through activities: receiving, carrying out, appreciating, living, and practicing. Knowledge is acquired through activities: knowing, understanding, applying, analyzing, evaluating, and creating. Skills are acquired through activities: observing, asking, trying, reasoning, presenting, and creating. The characteristics of competence and the differences in the acquisition process affect the Content Standards which include material.

\subsection{Discussion}

The scope of Arabic language subject matter in Madrasah Aliyah (Islamic Senior High School) according to KMA Number 165 of 2014 consists of material in the form of oral and written discourse. These materials include exposure or dialogue about introductions, family life, hobbies, work, youth, health, public facilities, tourism, Islamic stories, Islamic insights, Islamic holidays and Islamic figures to train the four aspects of language skills, namely listening, speaking, reading, and writing. Meanwhile, scope of Arabic subject matter at Islamic Senior High School according to KMA Number 183 of 2019 is as follows:

1. Materials in the form of oral and written discourse in the form of exposure or dialogue about introductions, family life, hobbies, work, youth, health, public facilities, tourism, Islamic stories, Islamic insights, Islamic holidays and Islamic figures Islam to train the four aspects of language skills that are listening, speaking, reading, and writing.

2. Communicative function: introducing oneself, introducing other people, country/regional origin, expressing wishes and family relationships, giving orders, prohibiting, asking permission, congratulating and responding, expressing opinions, asking for attention and giving announcements, descriptions of forms, scales, properties and characteristics of objects, asking for health conditions, expressions of visiting sick people, giving advice, saying goodbye, saying welcome and goodbye, asking past actions and events, asking for actions and events of the present and future, giving and asking for information about some teachings religion in Indonesia, comparing, describing events, appreciating a work, giving hope, asking the purpose of an activity.

As for more clearly to observe the similarities and differences in the material in KMA Number 165 of 2014 and KMA Number 183 of 2019 it is shown in the Table 1.

Table 1. Arabic Learning Materials at KMA 165 in 2014 and KMA 183 in 2019

\begin{tabular}{|c|c|}
\hline KMA 165 of 2014 & KMA 183 of 2019 \\
\hline \multicolumn{2}{|c|}{ Class X Semester 1} \\
\hline 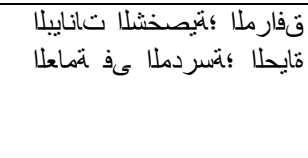 & 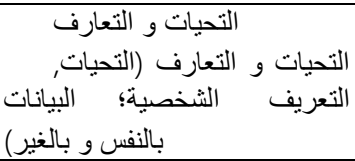 \\
\hline
\end{tabular}




\begin{tabular}{|c|c|}
\hline KMA 165 of 2014 & KMA 183 of 2019 \\
\hline 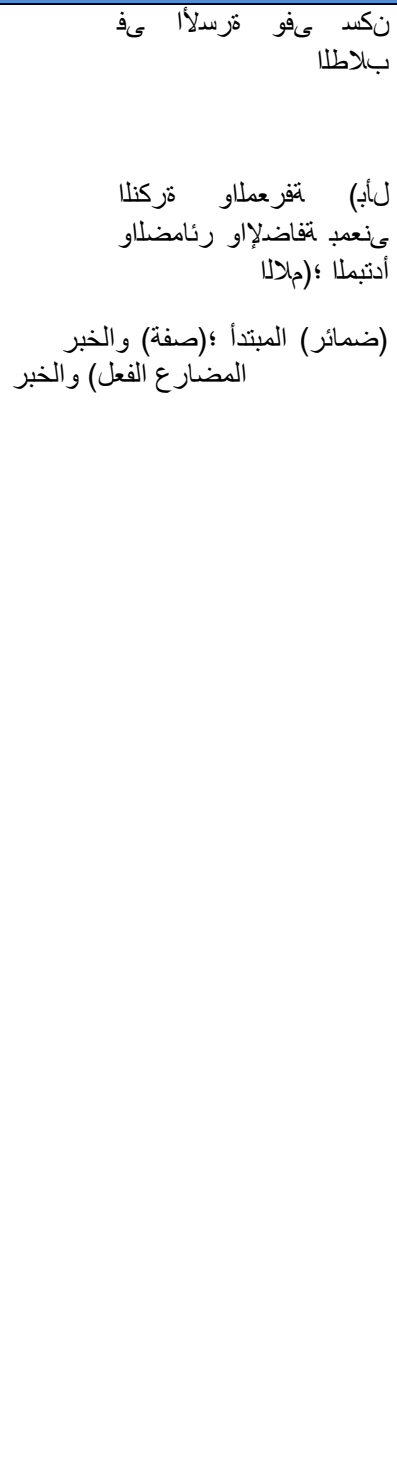 & 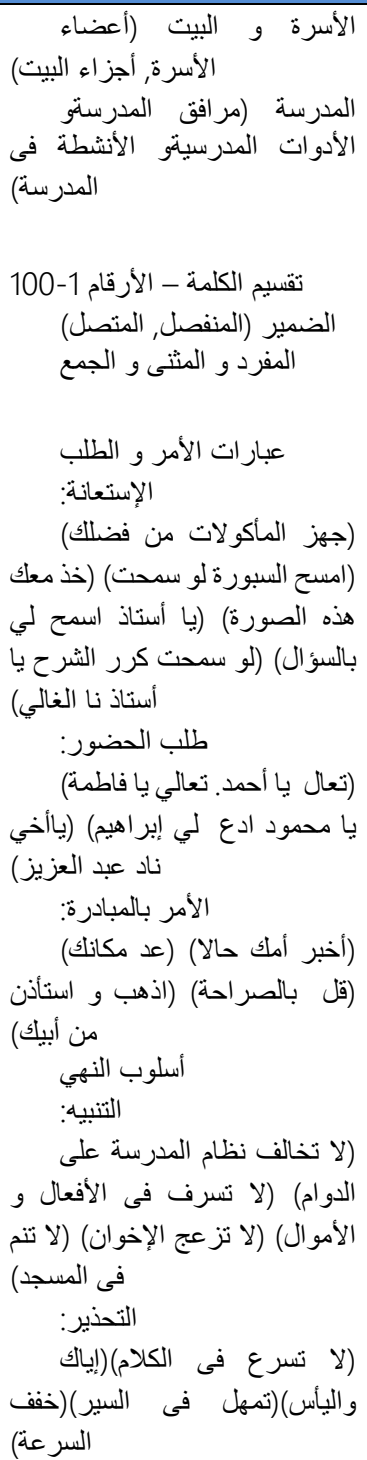 \\
\hline \multicolumn{2}{|c|}{ Class $X$ semester 2} \\
\hline 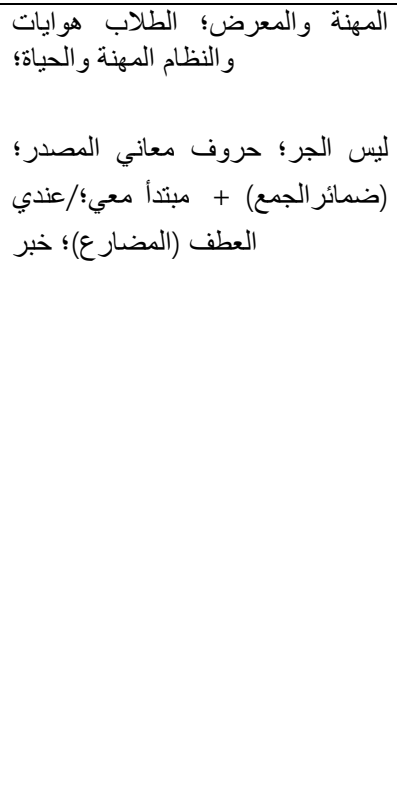 & 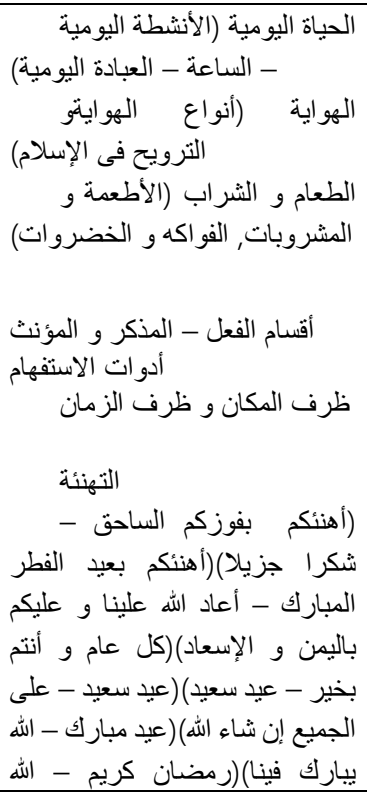 \\
\hline
\end{tabular}

\begin{tabular}{|c|c|}
\hline KMA 165 of 2014 & KMA 183 of 2019 \\
\hline & 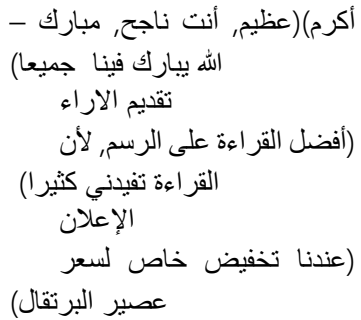 \\
\hline \multicolumn{2}{|c|}{ Class $X I$ semester 1} \\
\hline 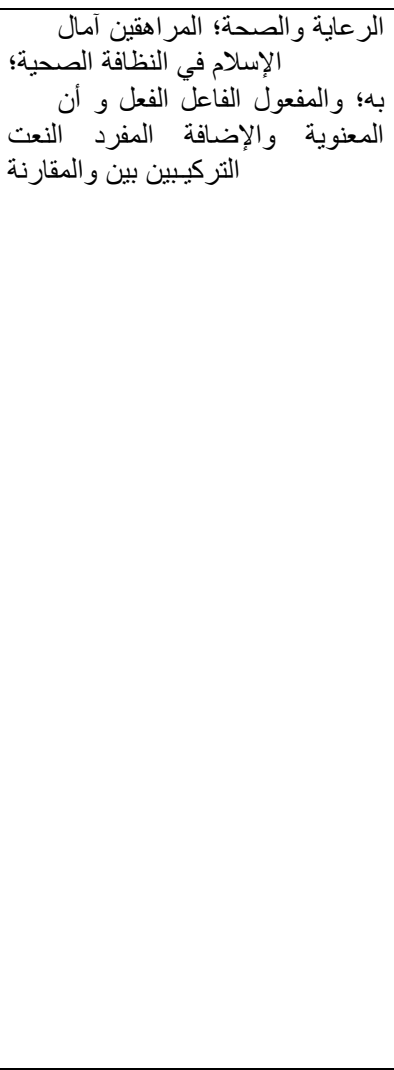 & 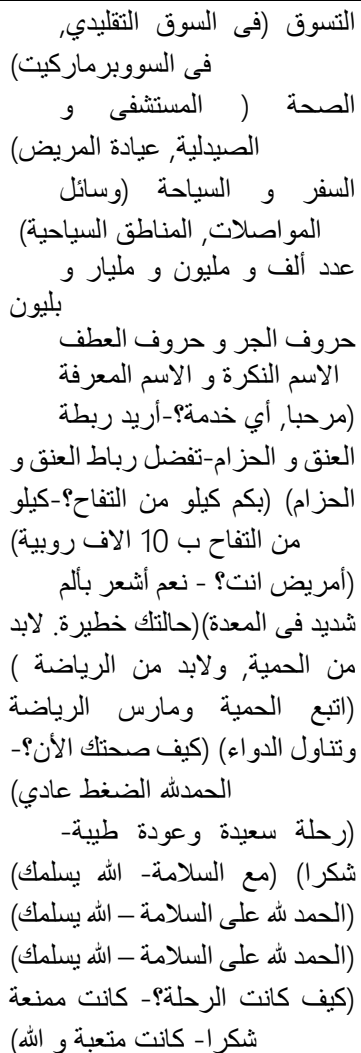 \\
\hline \multicolumn{2}{|c|}{ Class $X I$ semester 2} \\
\hline 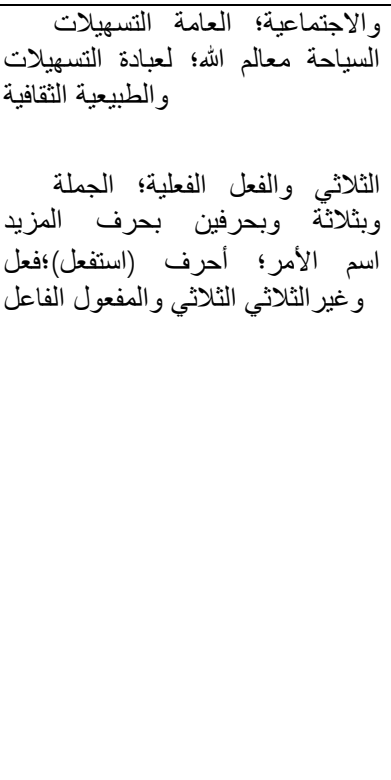 & 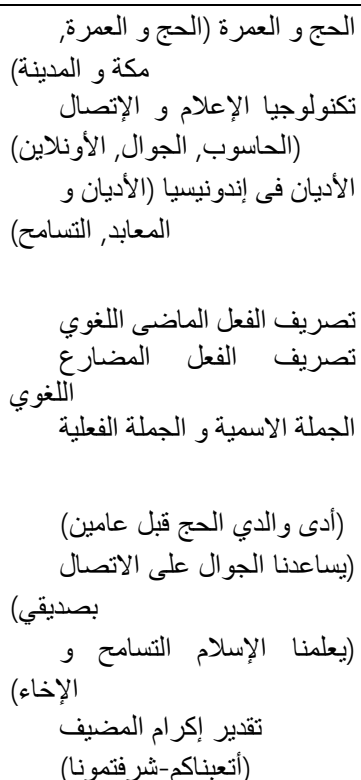 \\
\hline & \\
\hline
\end{tabular}




\begin{tabular}{|c|c|}
\hline KMA 165 of 2014 & KMA 183 of 2019 \\
\hline 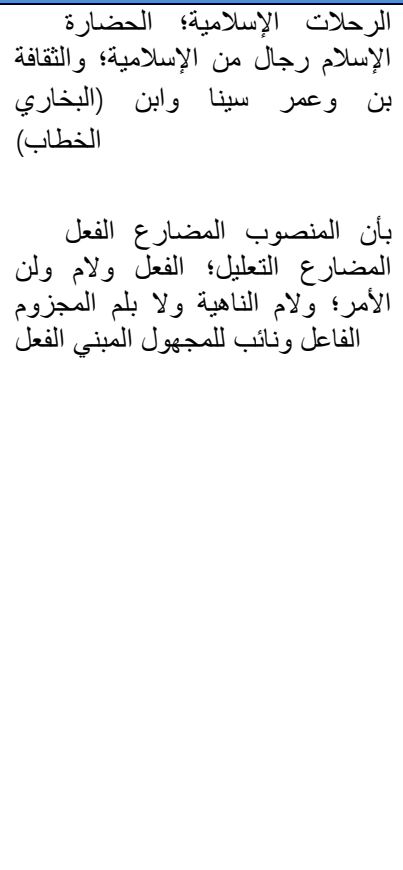 & 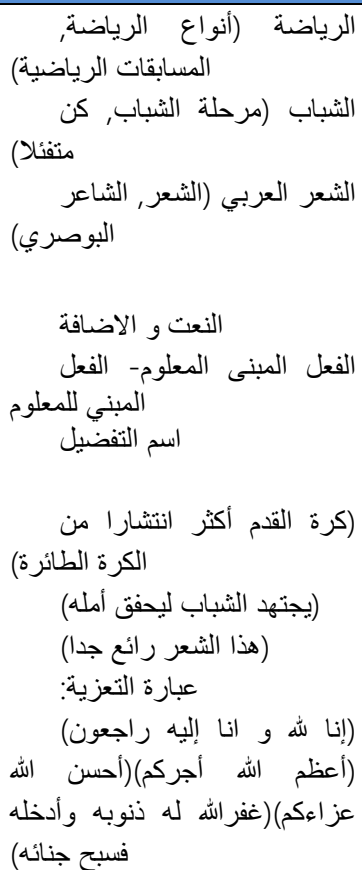 \\
\hline \multicolumn{2}{|c|}{ Class XII semester 2} \\
\hline - إبراهيم الإسلام؛ الخالق عن وألبحث & 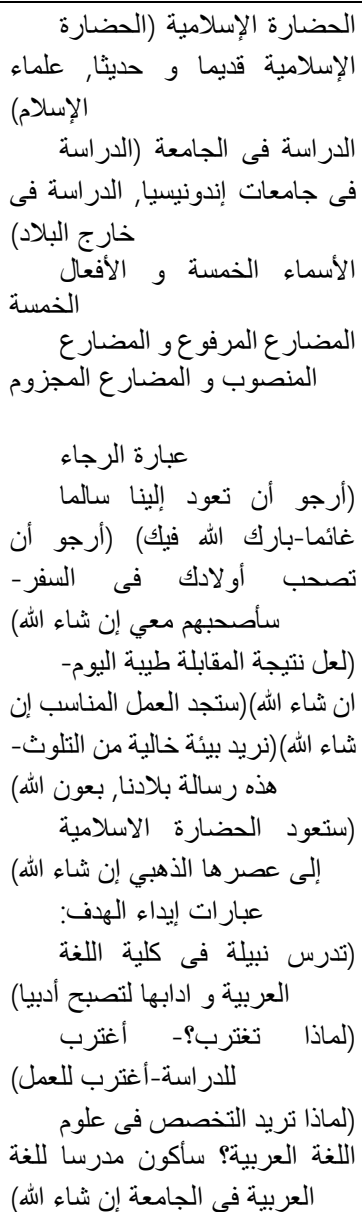 \\
\hline
\end{tabular}

The analysis of the similarities and differences in Arabic language material at Islamic Senior High School level in the curriculum 2013 between KMA Number 165 of 2014 and KMA Number 183 of 2019 will be presented in the following table:

Table 2. Similarities and Differences of Analysis of Islamic Senior High School Arabic material in the curriculum 2013 between KMA Number 165 of 2014 and KMA Number 183 of 2019

\begin{tabular}{|c|c|}
\hline Similarities & Differences \\
\hline $\begin{array}{l}\text { 1. Class X Semester } 1 \\
\text { The theme in the first } \\
\text { chapter is about } \\
\text { introductions and self- } \\
\text { identity }\end{array}$ & 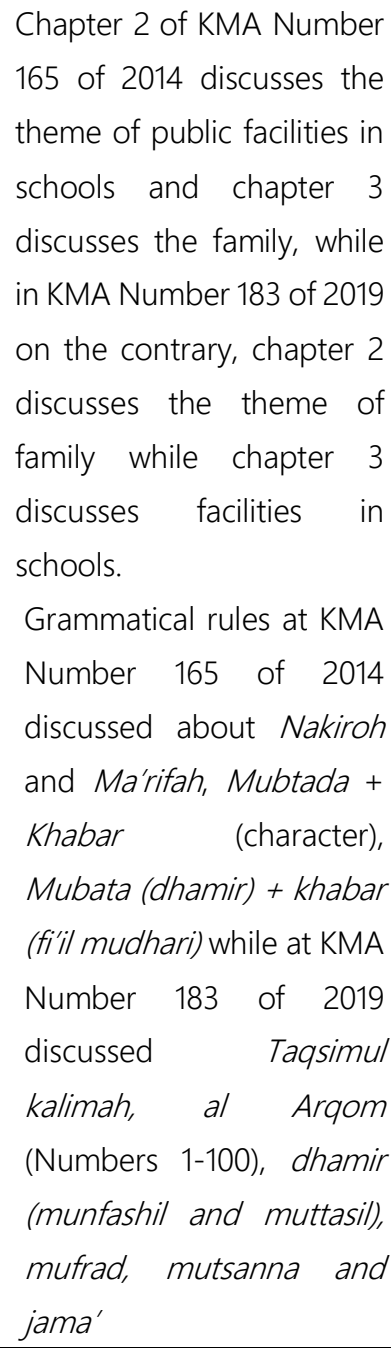 \\
\hline $\begin{array}{l}\text { 2. Class } X \text { semester } 2 \\
\text { The same theme in } \\
\text { even semesters is about } \\
\text { hiwayah (hobby) }\end{array}$ & $\begin{array}{l}\text { At KMA Number } 165 \text { of } \\
2014 \text {, the theme of hiwayah } \\
\text { (hobby) is in the first } \\
\text { chapter, while at KMA } \\
\text { Number } 183 \text { of } 2019 \text { it is } \\
\text { discussed in chapter } 2 \text {. } \\
\text { In the semester } 2 \text { the } \\
\text { themes discussed at KMA } \\
\text { Number } 165 \text { of } 2014 \text { were } \\
\text { about student hobbies, } \\
\text { professions and life, } \\
\text { professions } \\
\text { regulations, while KMA }\end{array}$ \\
\hline
\end{tabular}




\begin{tabular}{|c|c|}
\hline Similarities & Differences \\
\hline & $\begin{array}{l}\text { Number } 183 \text { of } 2019 \text { the } \\
\text { themes were about daily } \\
\text { life, hobbies, food and } \\
\text { drinks. } \\
\text { The grammatical rules at } \\
\text { KMA Number } 165 \text { of } 2014 \\
\text { discussed masdar, the } \\
\text { meaning of jerr, mubtada } \\
\text { (dhamir jama') + Khobar } \\
\text { (mudhari) and 'athaf, while } \\
\text { at KMA Number } 183 \text { of } 2019 \\
\text { discussed the division of } \\
\text { fi'il, mudzakar muannats, } \\
\text { adawatul istifham, dharaf } \\
\text { makan and dharaf zaman }\end{array}$ \\
\hline $\begin{array}{l}\text { 3. Class XI Semester } 1 \\
\text { There is a theme that is } \\
\text { still the same, which is } \\
\text { about Health }\end{array}$ & $\begin{array}{l}\text { At KMA Number } 165 \text { of } \\
2014 \text { the theme began with } \\
\text { the ideals and health of } \\
\text { teenagers, about health } \\
\text { and cleanliness in Islam, } \\
\text { while at KMA Number } 183 \\
\text { of } 2019 \text { the themes about } \\
\text { markets (traditional and } \\
\text { modern), health, travel and } \\
\text { tourism. } \\
\text { The grammatical rules at } \\
\text { KMA Number } 165 \text { of } 2014 \\
\text { discussed about í and fi'il } \\
\text { fa'il and maf'ul bih, na'at } \\
\text { mufrad and idhafah al } \\
\text { ma'nuwiyyah and the } \\
\text { relationship between the } \\
\text { two tarkib while at KMA } \\
\text { Number } 183 \text { of } 2019 \text { it } \\
\text { discussed the numbers } 100 \text {, } \\
1 \text { million, } 1 \text { billion and } 1 \\
\text { trillion, jerr and 'atahf, isim } \\
\text { nakiroh and isim ma'rifah }\end{array}$ \\
\hline $\begin{array}{l}\text { 4. Class XI Semester } 2 \\
\text { In class XI semester } 2 \\
\text { the same material is in } \\
\text { the discussion about } \\
\text { the Jumlah filiyyah }\end{array}$ & $\begin{array}{l}\text { At KMA Number } 165 \text { of } \\
2014 \text { the themes about } \\
\text { public and social facilities, } \\
\text { facilities for worship, forms } \\
\text { of cultural and natural }\end{array}$ \\
\hline
\end{tabular}

\begin{tabular}{|c|c|}
\hline Similarities & Differences \\
\hline & $\begin{array}{l}\text { tourism (the theme of } \\
\text { tourism), meanwhile at } \\
\text { KMA Number } 183 \text { of } 2019 \\
\text { was discussed in class XI } \\
\text { semester 1), while the } \\
\text { material theme at KMA } \\
\text { Number } 183 \text { of } 2019 \text { about } \\
\text { hajj and umrah, media and } \\
\text { communication technology } \\
\text { (computers, Hp, and } \\
\text { online), religions in } \\
\text { Indonesia (religions and } \\
\text { places of worship, } \\
\text { tolerance). } \\
\text { The grammatical rules at } \\
\text { KMA Number } 165 \text { of } 2014 \\
\text { discuss jumlah filiyyah, fi'il } \\
\text { tsulasi mazid biharfin wa bi } \\
\text { harfain wa bi tsalasati ahruf } \\
\text { (Jeim) fi'il amr, isim fa'il and } \\
\text { maf'ul tsulasi and those } \\
\text { who are not, while at KMA } \\
\text { Number 183 in } 2019 \text { it } \\
\text { discussed tashrif fi'il madhi } \\
\text { lughawi, tashrif fi'il } \\
\text { mudhari' lughawi, the } \\
\text { jumlah ismiyyahandjumlah } \\
\text { fi'liyyah. }\end{array}$ \\
\hline $\begin{array}{l}\text { 5. Class XII Semester } 1 \\
\text { In class XII semester 1, } \\
\text { the material in KMA } \\
\text { Number } 165 \text { of } 2014 \\
\text { and KMA Number } 183 \\
\text { of } 2019 \text { is different and } \\
\text { there is no theme of the } \\
\text { same material. }\end{array}$ & $\begin{array}{l}\text { At KMA Number } 165 \text { of } \\
2014 \text { the theme about } \\
\text { Islamic civilization, tourism } \\
\text { and Islamic culture, Islamic } \\
\text { figures (al Bukhari, Ibn Sina, } \\
\text { and Umar bin Khattab), } \\
\text { while at KMA Number } 183 \\
\text { of } 2019 \text { the theme of the } \\
\text { material about sports } \\
\text { (various sports), sports } \\
\text { competitions), Youth, Syi'ir } \\
\text { Arab. } \\
\text { The grammatical rules at } \\
\text { KMA Number } 165 \text { of } 2014 \\
\text { discussed fi'il mudhari' }\end{array}$ \\
\hline
\end{tabular}




\begin{tabular}{|c|c|}
\hline Similarities & Differences \\
\hline & 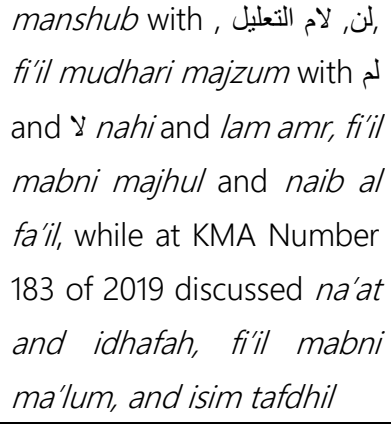 \\
\hline $\begin{array}{l}\text { 6. Class XII Semester } 2 \\
\text { In class XII semester 2, } \\
\text { the material in KMA } \\
\text { Number } 165 \text { of } 2014 \\
\text { and KMA Number } 183 \\
\text { of } 2019 \text { is different and } \\
\text { there is no theme of the } \\
\text { same material. }\end{array}$ & $\begin{array}{l}\text { At KMA Number } 165 \text { of } \\
2014 \text { the material themes } \\
\text { about Islamic holidays, } \\
\text { Abraham and discussions } \\
\text { about God, while the } \\
\text { material themes at KMA } \\
\text { Number } 183 \text { of } 2019 \\
\text { discussed Islamic } \\
\text { civilization } \quad \text { Islamic } \\
\text { modern and } \\
\text { civilizations, } \\
\text { scholars) which were } \\
\text { previously discussed at } \\
\text { KMA Number } 165 \text { in } 2014 \text { in } \\
\text { semesters } 1 \text { and the theme } \\
\text { is about studying at } \\
\text { universities (universities in } \\
\text { Indonesia and abroad). } \\
\text { The grammatical rules at } \\
\text { KMA Number } 165 \text { of } 2014 \\
\text { discussed muraja'ah } \\
\text { marfu'atul asthma', maf'ul } \\
\text { muthlak, maf'ul liajlih, and } \\
\text { muraja'ah manshubatul } \\
\text { asthma', while at KMA } \\
\text { Number } 183 \text { of } 2019 \text { they } \\
\text { discussed al asthma al } \\
\text { khomsah, al af'al al } \\
\text { momsah, mudhari' manshub, }\end{array}$ \\
\hline
\end{tabular}

\begin{tabular}{|l|l|}
\hline \multicolumn{1}{|c|}{ Similarities } & \multicolumn{1}{|c|}{ Differences } \\
\hline & $\begin{array}{l}\text { Number } 183 \text { of } 2019 \text { is } \\
\text { inserted communicative } \\
\text { expressions that can be } \\
\text { used to communicate } \\
\text { actively using Arabic }\end{array}$ \\
\hline
\end{tabular}

From this analysis, it can be seen that there are many material updates from KMA Number 165 of 2014 to KMA Number 183 of 2019. The material themes contained in KMA Number 183 of 2019 are more recent. For example, raising themes related to media and technology, modern markets, religions in Indonesia and tolerance, universities, as well as several themes that still have a lot of more contemporary vocabulary. In this case, the material at KMA Number 183 of 2019 is relevant to the purpose of the issuance of a decree made by the Ministry of Religious Affairs of the Republic of Indonesia KMA Number 183 of 2019 concerning the Islamic Education Curriculum and Arabic Language at Madrasah, as a form of effort in responding to the very fast changing times and demands of the global world.

Meanwhile, based on the material selection criteria according to W. S. Winkel, both KMA Number 165 of 2014 and KMA Number 183 of 2019 have been met. The material from the two KMAs is relevant to the teaching and learning objectives achieved, relevant to students' daily experiences, because the material raised is related to the daily life experienced by students. In terms of the level of difficulty with students' abilities, it is appropriate because the material is arranged in order from lowerlevel intellectual skills to high-level intellectual skills. For example, the theme of the material from class $\mathrm{X}$ to class XII is taken from the simplest themes that are easily obtained by students, namely introductions, self-identity, hobbies, family and so on. Then for the advanced level the themes are more specific and complex, such as themes about technology, Islamic civilization, getting to know Islamic figures, religions in Indonesia and so forth. As for the grammatical aspect, the material is also arranged from the lowest level such as the division of words in Arabic, numbers, and more. Then the material proceeds with more specific and complicated grammatical rules in advanced classes. In terms of subject matter can be adapted to the available media of teaching in the school.

From the description of the comparison between KMA Number 165 of 2014 and KMA Number 183 of 2019 can be a reference for Arabic teachers in understanding the essence of the current curriculum change. In addition, this research can be used as a reference for making textbooks containing relevant subject matter and making appropriate learning media. 


\section{CONCLUSION}

Based on the descriptions and analyzes that have been put forward by the researchers related to the comparative study of material aspects of the Arabic language subjects at the Islamic Senior High School at KMA Number 165 of 2014 and KMA Number 183 of 2019 resulted in the conclusion that the material in KMA Number 165 of 2014 and KMA Number 183 of 2019 have similarities and difference. The similarities include themes related to introductions, family hobbies, public facilities, health, tourism, Islamic civilization, and Islamic figures. In terms of material selection criteria, the two KMAs are appropriate. While the differences, among others, in KMA Number 183 of 2019 there are materials that have not been discussed at KMA Number 165 of 2014 including themes related to media and technology, food and beverages, markets, religion in Indonesia and universities. In terms of grammatical material, the difference between KMA Number 183 of 2019 is that the discussion is more composed of basic levels, such as from word discussion, introduction of pronouns, then a more in-depth discussion of sentences at a higher level. Meanwhile, at KMA Number 165 of 2014, the grammatical material was more random but specific.

KMA Number 183 of 2019 is a renewal and refinement of the mindset from KMA Number 165 of 2014. KMA Number 183 of 2019 was made on the basis of the times and demands of the global world so that many changes occurred. New materials and new vocabulary provide up-to-date knowledge for teachers and students. So that Arabic subjects at Islamic Senior High School are more applicable in use in everyday life.

\section{AUTHORS' CONTRIBUTIONS}

All authors have different roles in the accomplishment of the study. For this manuscript, they contributed equally to the process of drafting, revision, and approval of the final revision.

\section{REFERENCES}

[1] Kementerian Agama Republik Indonesia, Keputusan Menteri Agama Number 183 tahun 2019 tentang Kurikulum PAI dan Bahasa Arab pada Madrasah, Direktorat KSKK Madrasah, Direktorat Jenderal Pendidian Islam, 2019.

[2] Kementerian Agama Republik Indonesia, Lampiran Keputusan Menteri Agama Republik Indonesia Nomor: 165 Tahun 2014 tentang Kurikulum 2013 Mata Pelajaran Pendidikan Agama Islam dan Bahasa Arab pada Madrasah, 2014.

[3] Rusman, Model-Model Pembelajaran: Mengembangkan Profesionalisme Guru, Jakarta: RajaGrafindo Persada, 2010.
[4] M. Sari, Asmendri, Penelitian Kepustakaan (Library Research) dalam Penelitian Pendidikan IPA, Natural Science: Jurnal Penelitian Bidang IPA dan Pendidikan IPA, 6 (1) (2020) 41-43.

[5] Afifudin, B. A. Saebani, Metode Penelitian Kualitatif, Bandung: CV. Pustaka Setia, 2009.

[6] Isdisusilo, Panduan Lengkap Menyusun Silabus dan Rencana Pelaksanaan Pembelajaran, Jakarta: Kata Pena, 2012.

[7] Wina, Made, Strategi Pembelajaran Inovatif Kontemporer, Jakarta: Bumi Aksara, 2009.

[8] Asyrofi, Syamsuddin, Metodologi Pembelajaran Bahasa Arab, Yogyakarta: Idea Press, 2010. 